\title{
ARTRITIS GOUT DAN PERKEMBANGANNYA
}

\author{
Fandi Wahyu Widyanto
}

Rumah Sakit Aminah Blitar

Email funday_hoho@yahoo.com

\begin{abstract}
Abstrak
Artritis Gout dan Perkembangannya. Latar Belakang. Artritis gout merupakan istilah yang dipakai untuk kelompok gangguan metabolik, yang ditandai oleh meningkatnya konsentrasi asam urat (hiperurisemia). Setiap tahun penderita artritis gout meningkat jumlahnya dan merupakan bagian dari masalah utama kesehatan bagi usia lanjut di Indonesia maupun seluruh dunia. Oleh karena itu, penatalaksanaan artritis gout harus dilakukan dengan cermat agar tidak menimbulkan kecacatan yang lebih parah. Obat yang dipakai untuk artritis gout akut ialah kolkisin, obat antiinflamasi non-steroid atau kortikosteroid. Kolkisin juga dipakai sebagai terapi pencegahan. Diet dan perubahan cara hidup merupakan komponen yang penting dalam penatalaksanaan gout karena menurunkan kadar asam urat serum. Dengan pengobatan dini, pemantauan yang ketat disertai pendidikan terhadap penderita, prognosis umumnya baik.
\end{abstract}

\section{Abstract}

Gout Arthritis and Its Progress Background. Gout arthritis is the term used for a group of metabolic disorder. The sign of this disease is marked by increasing the level of uric acid (byperuricemia). The patient of gout arthritis continues to grow every year and becomes the part of health problem for the elderly not only in Indonesia but also a worldwide health problem. Therefore the theraphy of gout arthritis should be done carefully in order to diminish the disability. Colchicine, nonsteroidal anti-inflammatory drugs and corticosteroid are drugs used for treating acute gouty arthritis. Colchicine is also used for prophylaxis. Urate lowering drugs also play a role in prophylactic management of gout. With early intervention, careful monitoring, and patient education, the prognosis is excellent.

Key words : gout arthritis, hyperuricemia

\section{PENDAHULUAN}

Artritis gout merupakan salah satu penyakit metabolik (metabolic syndrom) yang terkait dengan pola makan diet tinggi purin dan minuman beralkohol. Penimbunan kristal monosodium urat (MSU) pada sendi dan jaringan lunak merupakan pemicu utama terjadinya keradangan atau inflamasi pada gout artritis (Nuki dan Simkin, 2006). Artritis gout adalah jenis artritis terbanyak ketiga setelah osteoartritis dan kelompok rematik luar sendi (gangguan pada komponen penunjang sendi, peradangan, penggunaan berlebihan) (Nainggolan, 2009). Penyakit ini mengganggu kualitas hidup penderitanya. Peningkatan kadar asam urat dalam darah (hiperurisemia) merupakan faktor utama terjadinya artritis gout (Roddy dan Doherty, 2010). Masalah akan timbul jika terbentuk kristal-kristal monosodium urat (MSU) pada sendisendi dan jaringan sekitarnya. Kristal-kristal berbentuk seperti jarum ini mengakibatkan reaksi peradangan yang jika berlanjut akan menimbulkan nyeri hebat yang sering menyertai serangan artritis gout (Carter, 2006).

Data NHANES III pada tahun 1988 hingga 1994 di Amerika Serikat menunjukkan bahwa artritis gout menyerang lebih dari 3 juta pria dengan usia 40 tahun atau lebih, dan 1,7 juta wanita dengan usia 40 tahun atau lebih (Weaver, 2008). Sedangkan di tahun 2007 hingga 2008 penderita artritis gout meningkat menjadi 8,3 juta penderita, dimana jumlah penderita artritis gout pada pria sebesar 6,1 juta penderita dan penderita wanita berjumlah 2,2 juta. Hal ini menunjukkan bahwa prevalensi penderita artritis gout di Amerika Serikat meningkat dalam dua dekade ini (Zhu et al, 2011).

Di Indonesia belum banyak publikasi epidemiologi tentang artritis gout. Berdasarkan laporan Dinas Kesehatan Propinsi Jawa Tengah, jumlah kasus artritis gout dari tahun ke tahun mengalami peningkatan di bandingkan dengan kasus penyakit tidak menular lainnya. Pada tahun 2007 jumlah kasus artritis gout di Tegal sebesar 5,7\% meningkat menjadi $8,7 \%$ pada tahun 2008 , dari data rekam medik di RSU Kardinah selama tahun 2008 tercatat 1068 penderita baik rawat inap maupun penderita rawat jalan yang melakukan pemeriksaan kadar asam urat $40 \%$ di antaranya menderita hiperurisemia (Purwaningsih, 2009).

Hasil survei WHO-ILAR Copcord (World Health Organization-International League of Associations for Rheumatology Community Oriented Program for Control of Rheumatic Disease) di pedesaan Sulawesi Utara dan Manado menemukan hubungan asam urat menahun dengan pola konsumsi dan gaya hidup, diantaranya konsumsi alkohol dan kebiasaan makan makanan kaya purin. Selain itu, kebiasaan minum 
obat jenis diuretika (hidroklorotiazide), yaitu obat untuk menurunkan tekanan darah tinggi dapat meningkatkan kadar asam urat serum (Muniroh et al, 2010).

Perubahan gaya hidup tradisional ke gaya hidup modern merupakan pemicu utama artritis gout (Saag dan Choi, 2006). Sebagian besar kasus artritis gout mempunyai latar belakang penyebab primer, sehingga memerlukan pengendalian kadar asam urat jangka panjang. Perlu komunikasi yang baik dengan penderita untuk mencapai tujuan terapi. Hal itu dapat diperoleh dengan edukasi dan diet rendah purin yang baik. Pencegahan lainnya berupa penurunan konsumsi alkohol dan penurunan berat badan (Hidayat, 2009).

Tujuan dari penulisan ini adalah untuk mengetahui perkembangan artritis gout meliputi epidemiologi, faktor resiko, patogenesis, manifestasi klinis penatalaksanaan, dan komplikasi prognosis serta perkembangan penyakit tersebut. Diharapkan dengan mengetahuinya dapat meningkatkan kualitas derajat kesehatan masyarakat, terutama berkaitan dengan artritis gout. Kemudian dapat menjadi salah satu tinjauan pustaka dalam penelitian-penelitian selanjutnya.

\section{PEMBAHASAN}

\section{Definisi}

Artritis gout adalah penyakit yang sering ditemukan dan tersebar di seluruh dunia. Artritis gout atau dikenal juga sebagai artritis pirai, merupakan kelompok penyakit heterogen sebagai akibat deposisi kristal monosodium urat pada jaringan atau akibat supersaturasi asam urat di dalam cairan ekstraseluler. Gangguan metabolisme yang mendasarkan artritis gout adalah hiperurisemia yang didefinisikan sebagai peninggian kadar urat lebih dari 7,0 $\mathrm{ml} / \mathrm{dl}$ untuk pria dan $6,0 \mathrm{ml} / \mathrm{dl}$ untuk wanita (Tehupeiory, 2006). Sedangkan definisi lain, artritis gout merupakan penyakit metabolik yang sering menyerang pria dewasa dan wanita posmenopause. Hal ini diakibatkan oleh meningkatnya kadar asam urat dalam darah (hiperurisemia) dan mempunyai ciri khas berupa episode artritis gout akut dan kronis (Schumacher dan Chen, 2008).

\section{Epidemiologi}

Artritis gout menyebar secara merata di seluruh dunia. Prevalensi bervariasi antar negara yang kemungkinan disebabkan oleh adanya perbedaan lingkungan, diet, dan genetik (Rothschild, 2013). Di Inggris dari tahun 2000 sampai 2007 kejadian artritis gout 2,68 per 1000 penduduk, dengan perbandingan 4,42 penderita pria dan 1,32 penderita wanita dan meningkat seiring bertambahnya usia (Soriano et al, 2011). Di Italia kejadian artritis gout meningkat dari 6,7 per 1000 penduduk pada tahun 2005 menjadi 9,1 per 1000 penduduk pada tahun 2009 (Rothschild, 2013).

Sedangkan jumlah kejadian artritis gout di Indonesia masih belum jelas karena data yang masih sedikit. Hal ini disebabkan karena Indonesia memiliki berbagai macam jenis etnis dan kebudayaan, jadi sangat memungkinkan jika Indonesia memiliki lebih banyak variasi jumlah kejadian artritis gout (Talarima et al, 2012). Pada tahun 2009 di Maluku Tengah ditemukan 132 kasus, dan terbanyak ada di Kota Masohi berjumlah 54 kasus (Talarima et al, 2012). Prevalensi artritis gout di Desa Sembiran, Bali sekitar 18,9\%, sedangkan di Kota Denpasar sekitar 18,2\%. Tingginya prevalensi artritis gout di masyarakat Bali berkaitan dengan kebiasaan makan makanan tinggi purin seperti lawar babi yang diolah dari daging babi, betutu ayam/itik, pepes ayam/babi, sate babi, dan babi guling (Hensen, 2007).

\section{Etiologi}

Etiologi dari artritis gout meliputi usia, jenis kelamin, riwayat medikasi, obesitas, konsumsi purin dan alkohol. Pria memiliki tingkat serum asam urat lebih tinggi daripada wanita, yang meningkatkan resiko mereka terserang artritis gout. Perkembangan artritis gout sebelum usia 30 tahun lebih banyak terjadi pada pria dibandingkan wanita. Namun angka kejadian artritis gout menjadi sama antara kedua jenis kelamin setelah usia 60 tahun. Prevalensi artritis gout pada pria meningkat dengan bertambahnya usia dan mencapai puncak antara usia 75 dan 84 tahun (Weaver, 2008).

Wanita mengalami peningkatan resiko artritis gout setelah menopause, kemudian resiko mulai meningkat pada usia 45 tahun dengan penurunan level estrogen karena estrogen memiliki efek urikosurik, hal ini menyebabkan artritis gout jarang pada wanita muda (Roddy dan Doherty, 2010).Pertambahan usia merupakan faktor resiko penting pada pria dan wanita. Hal ini kemungkinan disebabkan banyak faktor, seperti peningkatan kadar asam urat serum (penyebab yang paling sering adalah karena adanya penurunan fungsi ginjal), peningkatan pemakaian obat diuretik, dan obat lain yang dapat meningkatkan kadar asam urat serum (Doherty, 2009).

Penggunaan obat diuretik merupakan faktor resiko yang signifikan untuk perkembangan artritis gout. Obat diuretik dapat menyebabkan peningkatan reabsorpsi asam urat dalam ginjal, sehingga menyebabkan hiperurisemia. Dosis rendah aspirin, umumnya diresepkan untuk kardioprotektif, juga meningkatkan kadar asam urat sedikit pada pasien usia lanjut. Hiperurisemia juga terdeteksi pada pasien yang memakai pirazinamid, etambutol, dan niasin (Weaver, 2008).

Obesitas dan indeks massa tubuh berkontribusi secara signifikan dengan resiko artritis gout. Resiko artritis gout sangat rendah untuk pria dengan indeks massa tubuh antara 21 dan 22 tetapi meningkat tiga kali lipat untuk pria yang indeks massa tubuh 35 atau lebih besar (Weaver, 2008). Obesitas berkaitan dengan terjadinya resistensi insulin. Insulin diduga meningkatkan reabsorpsi asam urat pada ginjal melalui urate anion exchanger transporter-1 (URAT1) atau melalui sodium dependent anion cotransporter pada brush border yang terletak pada membran ginjal bagian tubulus proksimal. Dengan adanya resistensi insulin akan mengakibatkan gangguan pada proses fosforilasi oksidatif sehingga kadar adenosin tubuh meningkat. Peningkatan konsentrasi adenosin mengakibatkan terjadinya retensi sodium, asam urat dan air oleh ginjal (Choi et al, 2005).

Konsumsi tinggi alkohol dan diet kaya daging serta makanan laut (terutama kerang dan beberapa ikan laut lain) meningkatkan resiko artritis gout. Sayuran yang banyak mengandung purin, yang sebelumnya dieliminasi dalam diet rendah purin, tidak ditemukan memiliki hubungan terjadinya hiperurisemia dan tidak meningkatkan resiko artritis gout (Weaver, 2008). Mekanisme biologi yang menjelaskan hubungan antara konsumsi alkohol dengan resiko terjadinya 
serangan gout yakni, alkohol dapat mempercepat proses pemecahan adenosin trifosfat dan produksi asam urat (Zhang, 2006). Metabolisme etanol menjadi acetyl Co $A$ menjadi adenin nukleotida meningkatkan terbentuknya adenosin monofosfat yang merupakan prekursor pembentuk asam urat. Alkohol juga dapat meningkatkan asam laktat pada darah yang menghambat eksresi asam urat (Doherty, 2009). Alasan lain yang menjelaskan hubungan alkohol dengan artritis gout adalah alkohol memiliki kandungan purin yang tinggi sehingga mengakibatkan over produksi asam urat dalam tubuh (Zhang, 2006).

Asam urat merupakan produk akhir dari metabolisme purin. Dalam keadaan normalnya, 90\% dari hasil metabolit nukleotida adenine, guanine, dan hipoxantin akan digunakan kembali sehingga akan terbentuk kembali masing-masing menjadi adenosine monophosphate (AMP), inosine monophosphate (IMP), dan guanine monophosphate (GMP) oleh adenine phosphoribosyl transferase (APRT) dan hipoxantin guanine phosphoribosyl transferase (HGPRT). Hanya sisanya yang akan diubah menjadi xantin dan selanjutnya akan diubah menjadi asam urat oleh enzim xantin oksidase (Silbernagl, 2006).

\section{Patologi}

Histopatologis dari tofus menunjukkan granuloma dikelilingi oleh butir kristal monosodium urat (MSU). Reaksi inflamasi di sekeliling kristal terutama terdiri dari sel mononuklir dan sel giant. Erosi kartilago dan korteks tulang terjadi di sekitar tofus. Kapsul fibrosa biasanya prominen di sekeliling tofus. Kristal dalam tofus berbentuk jarum (needle shape) dan sering membentuk kelompok kecil secara radier (Tehupeiory, 2006).

Komponen lain yang penting dalam tofus adalah lipid glikosaminoglikan dan plasma protein. Pada artritis gout akut cairan sendi juga mengandung kristal monosodium urat monohidrat pada 95\% kasus. Pada cairan aspirasi dari sendi yang diambil segera pada saat inflamasi akut akan ditemukan banyak kristal di dalam lekosit. Hal ini disebabkan karena terjadi proses fagositosis (Tehupeiory, 2006).

\section{Patogenesis}

Monosodium urat akan membentuk kristal ketika konsentrasinya dalam plasma berlebih, sekitar 7,0 mg/dl. Kadar monosodium urat pada plasma bukanlah satu-satunya faktor yang mendorong terjadinya pembentukan kristal. Hal ini terbukti pada beberapa penderita hiperurisemia tidak menunjukkan gejala untuk waktu yang lama sebelum serangan artritis gout yang pertama kali. Faktor-faktor yang mendorong terjadinya serangan artritis gout pada penderita hiperurisemia belum diketahui pasti. Diduga kelarutan asam urat dipengaruhi $\mathrm{pH}$, suhu, dan ikatan antara asam urat dan protein plasma (Busso dan So, 2010).

Kristal monosodium urat yang menumpuk akan berinteraksi dengan fagosit melalui dua mekanisme. Mekanisme pertama adalah dengan cara mengaktifkan sel-sel melalui rute konvensional yakni opsonisasi dan fagositosis serta mengeluarkan mediator inflamasi. Mekanisme kedua adalah kristal monosodium urat berinteraksi langsung dengan membran lipid dan protein melalui membran sel dan glikoprotein pada fagosit. Interaksi ini mengaktivasi beberapa jalur transduksi seperti protein $G$, fosfolipase C dan D, Srctyrosine-kinase, ERK1/ERK2, c-Jun N-terminal kinase, dan p38 mitogen-activated protein kinase. Proses diatas akan menginduksi pengeluaran interleukin (IL) pada sel monosit yang merupakan faktor penentu terjadinya akumulasi neutrofil (Choi et al, 2005).

Pengenalan kristal monosodium urat diperantarai oleh Toll-like receptor (TLR) 2 dan TLR 4, kedua reseptor tersebut beserta TLR protein penyadur MyD88 mendorong terjadinya fagositosis. Selanjutnya proses pengenalan TLR 2 dan 4 akan mengaktifkan faktor transkripsi nuclear factor-kB dan menghasilkan berbagai macam faktor inflamasi (Cronstein dan Terkeltaub, 2006). Proses fagositosis kristal monosodium urat menghasilkan reactive oxygen species (ROS) melalui NADPH oksidase. Keadaan ini mengaktifkan NLRP3, kristal monosodium urat juga menginduksi pelepasan ATP yang nantinya akan mengaktifkan P2X7R. Ketika P2X7R diaktifkan akan terjadi proses pengeluaran cepat kalium dari dalam sel yang merangsang NLRP3. Kompleks makro melekular yang disebut dengan inflamasom terdiri dari NLRP3, ASC dan pro-caspase-1 dan CARDINAL. Semua proses diatas nantinya akan menghasilkan IL-1 $\alpha$ (Busso dan So, 2010).

Sel-sel yang sering diteliti pada artritis gout adalah lekosit, neutrofil, dan makrofag (Busso dan So, 2010). Salah satu komponen utama pada inflamasi akut adalah pengaktifan vascular endhotelial yang menyebabkan vasodilatasi dengan peningkatan aliran darah, peningkatan permeabilitas terhadap protein plasma dan pengumpulan lekosit ke dalam jaringan. Aktivasi endotel akan menghasilkan molekul adhesi seperti E-selectin, intercellular adhesion molecule-1 (ICAM-1) dan vascular cell adhesion molecule-1 (VCAM-1) yang kemungkinan disebabkan karena adanya faktor TNF- $\alpha$ yang dikeluarkan oleh sel mast (Dalbeth dan Haskard, 2005).

Neutrofil berkontribusi pada proses inflamasi melalui faktor kemotaktik yakni sitokin dan kemokin yang berperan pada adhesi endotel dan proses transmigrasi. Sejumlah faktor yang diketahui berperan dalam proses artritis gout adalah IL-1 $\alpha$, IL-8, CXCL1, dan granulocyte stimulating-colony factor (Busso dan So, 2010).

\section{Tabel 1. Penyebab Umum Overproduksi dan Ekskresi yang menurun dari asam urat pada artritis gout}

\begin{tabular}{|c|c|}
\hline Over produksi & Ekskresi yang menurun \\
\hline $\begin{array}{l}\text { - Makanan dengan } \\
\text { kandungan purin } \\
\text { tinggi (misalnya, } \\
\text { kerang, tiram, } \\
\text { daging merah, hati, } \\
\text { ikan teri) } \\
\text { - Alkohol } \\
\text { - Kekurangan enzim } \\
\text { (misalnya, } \\
\text { fosforibosiltransfer } \\
\text { ase hipoksantin- } \\
\text { guanin, } \\
\text { phosphoribosyl } \\
\text { pirofosfat) } \\
\text { Obesitas } \\
\text { Peningkatan } \\
\text { pergantian sel } \\
\text { Keganasan } \\
\text { Psoriasis }\end{array}$ & $\begin{array}{l}\text { - Penyakit ginjal } \\
\text { - Intoksikasi } \\
\text { - Obat-obatan } \\
\text { (misalnya diuretik, } \\
\text { siklosporin, aspirin } \\
\text { dosis rendah, } \\
\text { pirazinamid, niasin, } \\
\text { etambutol) } \\
\text { - Asidosis metabolik } \\
\text { (misalnya, } \\
\text { ketoasidosis, } \\
\text { asidosis laktat) } \\
\text { Alkohol }\end{array}$ \\
\hline
\end{tabular}

(Sunkureddi et al, 2006) 
Penurunan konsentrasi asam urat serum dapat mencetuskan pelepasan kristal monosodium urat dari depositnya dalam tofus (crystals shedding). Pada beberapa pasien gout atau yang dengan hiperurisemia asimptomatik kristal urat ditemukan pada sendi metatarsofalangeal dan lutut yang sebelumnya tidak pernah mendapat serangan akut. Dengan demikian gout dapat timbul pada keadaan asimptomatik (Tehupeiory, 2006).

Peradangan atau inflamasi merupakan reaksi penting pada artritis gout. Reaksi ini merupakan reaksi pertahanan tubuh non spesifik untuk menghindari kerusakan jaringan akibat agen penyebab. Tujuan dari proses inflamasi itu adalah untuk menetralisir dan menghancurkan agen penyebab serta mencegah perluasan agen penyebab ke jaringan yang lebih luas (Tehupeiory, 2006). Reaksi inflamasi yang berperan dalam proses melibatkan makrofag, neutrofil, yang nantinya menghasilkan berbagai mediator kimiawi antara lain, TNF$\alpha$, interleukin-1, interleukin-6, interleukin-8, alarmin, dan leukotrien (Neogi, 2011).

\section{Manifestasi Klinis}

Gambaran klinis artritis gout terdiri dari artritis gout asimptomatik, artritis gout akut, interkritikal gout, dan gout menahun dengan tofus. Nilai normal asam urat serum pada pria adalah $5,1 \pm 1,0 \mathrm{mg} / \mathrm{dl}$, dan pada wanita adalah $4,0 \pm 1,0 \mathrm{mg} / \mathrm{dl}$. Nilai-nilai ini meningkat sampai $9-10 \mathrm{mg} /$ $\mathrm{dl}$ pada seseorang dengan artritis gout (Carter, 2006). Pada tahap pertama hiperurisemia bersifat asimptomatik, kondisi ini dapat terjadi untuk beberapa lama dan ditandai dengan penumpukan asam urat pada jaringan yang sifatnya silent. Tingkatan hiperurisemia berkolerasi dengan terjadinya serangan artritis gout pada tahap kedua (Sunkureddi et al, 2006).

Radang sendi pada stadium ini sangat akut dan yang timbul sangat cepat dalam waktu singkat. Pasien tidur tanpa ada gejala apa-apa. Pada saat bangun pagi terasa sakit yang hebat dan tidak dapat berjalan. Biasanya bersifat monoartikuler dengan keluhan utama berupa nyeri, bengkak, terasa hangat, merah dengan gejala sistemik berupa demam, menggigil dan merasa lelah (Tehupeiory, 2006).

Serangan artritis gout akut terjadi ditandai dengan nyeri pada sendi yang berat dan biasanya bersifat monoartikular. Pada 50\% serangan pertama terjadi pada metatarsophalangeal1 (MTP-1) yang biasa disebut dengan podagra. Semakin lama serangan mungkin bersifat poliartikular dan menyerang ankles, knee, wrist, dan sendi-sendi pada tangan (Sunkureddi et all, 2006). Serangan akut ini dilukiskan sebagai sembuh beberapa hari sampai beberapa minggu, bila tidak terobati, rekuren yang multipel, interval antara serangan singkat dan dapat mengenai beberapa sendi (Tehupeiory, 2006). Ketika serangan artritis gout terjadi eritema yang luas di sekitar area sendi yang terkena dapat terjadi. Meskipun serangan bersifat sangat nyeri biasanya dapat sembuh sendiri dan hanya beberapa hari. Setelah serangan terdapat interval waktu yang sifatnya asimptomatik dan disebut juga stadium interkritikal (Sunkureddi et al, 2006).

Faktor pencetus serangan akut antara lain berupa trauma lokal, diet tinggi purin, kelelahan fisik, stres, tindakan operasi, pemakaian obat diuretik atau penurunan dan peningkatan asam urat. Penurunan asam urat darah secara mendadak dengan alopurinol atau obat urikosurik dapat menimbulkan kekambuhan (Tehupeiory, 2006).

Stadium interkritikal merupakan kelanjutan stadium akut dimana terjadi periode interkritik asimptomatik. Walaupun secara klinis tidak didapatkan tanda-tanda radang akut, namun pada aspirasi sendi ditemukan kristal urat. Hal ini menunjukkan bahwa proses peradangan tetap berlanjut, walaupun tanpa keluhan. Keadaan ini dapat terjadi satu atau beberapa kali pertahun, atau dapat sampai 10 tahun tanpa serangan akut. Apabila tanpa penanganan yang baik dan pengaturan asam urat yang tidak benar, maka dapat timbul serangan akut lebih sering yang dapat mengenai beberapa sendi dan biasanya lebih berat (Tehupeiory, 2006). Kebanyakan orang mengalami serangan artritis gout berulang dalam waktu kurang dari 1 tahun jika tidak diobati (Carter, 2006). Segera setelah serangan akut terjadi penderita mungkin mengalami proses yang terus berlanjut, meskipun bersifat asimptomatik apabila terapi antiinflamasi tidak diberikan pada waktu yang cukup, yaitu beberapa hari setelah serangan akut berhenti. Setelah itu terdapat jeda waktu yang lama sebelum serangan berikutnya. Selama waktu ini deposit asam urat kemungkinan meningkat secara silent (Mandell, 2008).

Stadium gout menahun ini umumnya pada pasien yang mengobati sendiri sehingga dalam waktu lama tidak berobat secara teratur pada dokter. Artritis gout menahun biasanya disertai tofus yang banyak dan terdapat poliartikuler (Tehupeiory, 2006). Tofus terbentuk pada masa artritis gout kronis akibat insolubilitas relatif asam urat. Awitan dan ukuran tofus secara proporsional mungkin berkaitan dengan kadar asam urat serum. Bursa olekranon, tendon achilles, permukaan ekstensor lengan bawah, bursa infrapatelar, dan heliks telinga adalah tempat-tempat yang sering dihinggapi tofus. Secara klinis tofus ini mungkin sulit dibedakan dengan nodul rematik. Pada masa kini tofus jarang terlihat dan akan menghilang dengan terapi yang tepat (Carter, 2006).

Pada tofus yang besar dapat dilakukan ekstirpasi, namun hasilnya kurang memuaskan. Lokasi tofus yang paling sering pada cuping telinga, MTP-1, olekranon, tendon Achilles dan jari tangan. Pada stadium ini kadang-kadang disertai batu saluran kemih sampai penyakit ginjal menahun (Tehupeiory, 2006). Pada artritis gout kronis yang menyerang banyak sendi dapat menyerupai artritis reumatoid. Penderita dapat timbul tofus subkutaneus pada area yang mengalami gesekan atau trauma. Tofus tersebut dapat serng diduga sebagai nodul reumatoid (Mandell, 2008).

\section{Diagnosis}

Diagnosis artritis gout dilakukan sesuai dengan kriteria dari The American College of Rheumatology (ACR) yaitu terdapat kristal urat dalam cairan sendi atau tofus dan/atau bila ditemukan 6 dari 12 kriteria yaitu, Inflamasi maksimum pada hari pertama, serangan akut lebih dari satu kali, artritis monoartikuler, sendi yang terkena berwarna kemerahan, pembengkakan dan nyeri pada sendi metatarsofalangeal, serangan pada sendi metatarsofalangeal unilateral, adanya tofus, hiperurisemia, pada foto sinar-X tampak pembengkakan sendi asimetris dan kista subkortikal tanpa erosi, dan kultur bakteri cairan sendi negatif.

Sedangkan menurut Fauci et al (2008), diagnosis artritis gout meliputi kriteria analisis cairan sinovial, terdapat 
kristal-kristal asam urat berbentuk jarum baik di cairan eksraseluler maupun intraseluler, asam urat serum, asam urat urin, ekskresi $>800 \mathrm{mg} / \mathrm{dl}$ dalam diet normal tanpa pengaruh obat, yang menunjukkan overproduksi, skrining untuk menemukan faktor resiko, seperti urinalisis, serum kreatinin, tes fungsi hati, kadar glukosa dan lemak, dan hitung darah lengkap, jika terbukti karena overproduksi, konsentrasi eritrosit bypoxantine guanine phosporibosyl transferase (HGPRT) dan 5phosphoribosyl-1-pyrophosphate (PRPP) terbukti meningkat, foto sinar-X, menunjukkan perubahan kistik, erosi dengan garis tepi bersklerosi pada artritis gout kronis.

Artritis gout memiliki diagnosis banding seperti artritis septik, psoriasis, calcium pyrophosphate deposition disease (CPPD), dan artritis rematik. Untuk diagnosis definitif artritis gout dikonfirmasikan dengan analisis cairan sendi dimana pada penderita artritis gout mengandung monosodium urat yang negatif birefringent (refraktif ganda) yang juga ditelan oleh neutrofil (dilihat dengan mikroskop sinar terpolarisasi) (Setter dan Sonnet, 2005). Analisis cairan sinovial dan kultur sangat penting untuk membedakan artritis septik dengan artritis gout. Artritis gout cenderung tidak simetris dan faktor reumatoid negatif, sedangkan pada artritis rematik cenderung terjadi simetris dan lebih dari $60 \%$ kasus memiliki faktor reumatoid positif. Hiperurisemia juga sering terjadi pada penderita psoriasis dan adanya lesi kulit membedakan kasus ini dengan artritis gout (Depkes, 2006).

\section{Penatalaksanaan}

Tujuan pengobatan pada penderita artritis gout adalah untuk mengurangi rasa nyeri, mempertahankan fungsi sendi dan mencegah terjadinya kelumpuhan. Terapi yang diberikan harus dipertimbangkan sesuai dengan berat ringannya artrtitis gout (Neogi, 2011). Penatalaksanaan utama pada penderita artritis gout meliputi edukasi pasien tentang diet, lifestyle, medikamentosa berdasarkan kondisi obyektif penderita, dan perawatan komorbiditas (Khanna et al, 2012).

Pengobatan artritis gout bergantung pada tahap penyakitnya. Hiperurisemia asiptomatik biasanya tidak membutuhkan pengobatan. Serangan akut artritis gout diobati dengan obat-obatan antiinflamasi nonsteroid atau kolkisin. Obat-obat ini diberikan dalam dosis tinggi atau dosis penuh untuk mengurangi peradangan akut sendi (Carter, 2006).

Beberapa lifestyle yang dianjurkan antara lain menurunkan berat badan, mengkonsumsi makanan sehat, olahraga, menghindari merokok, dan konsumsi air yang cukup. Modifikasi diet pada penderita obesitas diusahakan untuk mencapai indeks masa tubuh yang ideal, namun diet yang terlalu ketat dan diet tinggi protein atau rendah karbohidrat (diet atkins) sebaiknya dihindari. Pada penderita artritis gout dengan riwayat batu saluran kemih disarankan untuk mengkonsumsi 2 liter air tiap harinya dan menghindari kondisi kekurangan cairan. Untuk latihan fisik penderita artritis gout sebaiknya berupa latihan fisik yang ringan, karena dikhawatirkan akan menimbulkan trauma pada sendi (Jordan et al, 2007).

Penanganan diet pada penderita artritis gout dikelompokkan menjadi 3 kelompok, yaitu avoid, limit, dan encourage. Pada penderita yang dietnya diatur dengan baik mengalami penurunan kadar urat serum yang bermakna (Khanna et all, 2012).

Tujuan terapi serangan artritis gout akut adalah menghilangkan gejala, sendi yang sakit harus diistirahatkan dan terapi obat dilaksanakan secepat mungkin untuk menjamin respon yang cepat dan sempurna. Ada tiga pilihan obat untuk artritis gout akut, yaitu NSAID, kolkisin, kortikosteroid, dan memiliki keuntungan dan kerugian. Pemilihan untuk penderita tetentu tergantung pada beberapa faktor, termasuk waktu onset dari serangan yang berhubungan dengan terapi awal, kontraindikasi terhadap obat karena adanya penyakit lain, efikasi serta resiko potensial.NSAID biasanya lebih dapat ditolerir dibanding kolkhisin dan lebih mempunyai efek yang dapat diprediksi (Depkes, 2006).

Untuk penderita artritis gout yang mengalami peptic ulcers, perdarahan atau perforasi sebaiknya mengikuti standar atau guideline penggunaan NSAID. Kolkisin dapat menjadi alternatif namun memiliki efek kerja yang lebih lambat dibandingkan dengan NSAID. Kortikosteroid baik secara oral, intraartikular, intramuskular, ataupun intravena lebih efektif diberikan pada gout monoartritis, penderita yang tidak toleran terhadap NSAID dan penderita yang mengalami refrakter terhadap pengobatan lainnya (Jordan et al, 2007).

Untuk mendapatkan hasil yang optimal, sebaiknya pengobatan serangan artritis gout diobati dalam 24 jam pertama serangan, salah satu pertimbangan pemilihan obat adalah berdasarkan tingkatan nyeri dan sendi yang terkena. Terapi kombinasi dapat dilakukan pada kondisi akut yang berat dan serangan artritis gout terjadi pada banyak sendi besar. Terapi kombinasi yang dilakukan adalah kolkisin dengan NSAID, kolkisin dan kortikosteroid oral, steroid intraartikular dan obat lainnya. Untuk kombinasi NSAID dengan kortikosteroid sistemik tidak disarankan karena dikawatirkan menimbulkan toksik pada saluran cerna (Khanna et al, 2012). Obat golongan NSAID yang di-rekomendasikan sebagai lini pertama pada kondisi artritis gout akut adalah indometasin, naproxen, dan sulindak. Ketiga obat tersebut dapat menimbulkan efek samping serius pada saluran cerna, ginjal, dan perdarahan saluran cerna. Obat golongan cyclooxigenase 2 inhibitor (COX 2 inhibitor) seperti celecoxib merupakan pilihan pada penderita artritis gout dengan masalah pada saluran cerna (Cronstein dan Terkeltaub, 2006).

Tabel 2. Contoh Obat NSAID

\begin{tabular}{lll}
\hline Nama obat & \multicolumn{1}{c}{$\begin{array}{c}\text { Rute } \\
\text { pemberian }\end{array}$} & \multicolumn{1}{c}{ Dosis } \\
\hline Aspirin & Oral & 4-6 gram/hari \\
Indometasin & Oral & 2-4kali $25 \mathrm{mg} /$ hari \\
Piroksikam & Oral & 10-20 mg/hari \\
Ibuprofen & Oral & $1200-2400 \mathrm{mg} /$ hari \\
$\begin{array}{l}\text { Asam } \\
\text { mefenamat }\end{array}$ & Oral & $750-1500 \mathrm{mg} /$ hari \\
$\begin{array}{l}\text { Meloksikam } \\
\text { Natrium }\end{array}$ & Oral & $7,5-15 \mathrm{mg} /$ hari \\
diklofenak & Oral & $100-150 \mathrm{mg} /$ hari \\
\hline
\end{tabular}

Kolkisin oral merupakan salah satu obat pilihan utama ketika terjadi serangan gout artritis akut, akan tetapi pemberian obat ini tidak dianjurkan pada penderita yang onset serangannya telah lebih dari 36 jam. Pemberian kolkisin 
dimulai dengan loading dosis sebesar 1,2 mg dan diikuti dengan $0,6 \mathrm{mg}$ satu jam kemudian sebagai profilaksis diberikan 12 jam kemudian dan dilanjutkan sampai serangan artritis gout akut berhenti dan dosis maksimal kolkisin 2 mg per hari (Khanna et al, 2012).

Pemilihan kortikosteroid sebagai terapi inisial serangan gout artritis akut direkomendasikan untuk mempertimbangkan jumlah sendi yang terserang. Satu atau dua sendi kecil yang terserang sebaiknya menggunakan kortikosteroid oral, namun jika sendi yang terserang adalah sendi besar, disarankan pemberian kortikosteroid intraartikular. Kortikosteroid oral dapat diberikan seperti prednison $0,5 \mathrm{mg} / \mathrm{kg} /$ hari dengan lama pemberian 5 sampai 10 hari atau 2 sampai 5 hari dengan dosis penuh kemudian ditappering off selama 7 sampai 10 hari (Khanna et al, 2012). Didapatkannya peran NLRP3 inflamasom yang mana menghasilkan IL-1â diasumsikan sitokin ini dapat menjadi target terapi untuk keadaan inflamasi artritis gout. IL-1 inhibitor, rilonacept juga menunjukkan keefektifan dalam menekan artritis gout akut dan kadar $\mathrm{C}$ reactive protein (Baker dan Schumacher, 2010).

Indikasi terapi hiperurisemia adalah tofus, gambaran radiografik adanya erosi akibat gout, nefrolitiasis karena asam urat, nefropati urat, profilaksis untuk kemoterapi yang menginduksi artritis gout, dan penderita kambuhan yang mengganggu kualitas hidup (Wesselman, 2005). Target terapi pada artritis gout adalah untuk mengurangi keluhan dan gejala dimana kadar asam urat yang dituju adalah sekurangkurangnya $<6 \mathrm{mg} / \mathrm{dl}$ atau $<5 \mathrm{mg} / \mathrm{dl}$. Obat golongan xantin oksidase inhibitor seperti alopurinol dan febuxostat direkomendasikan sebagai lini pertama untuk pengobatan atau urate lowering therapy (ULT) pada penderita artritis gout (Terkeltaub, 2009).

Dosis awal alopurinol yang diberikan sebaiknya tidak lebih dari $100 \mathrm{mg}$ perhari dan dosis ini dikurangi apabila didapatkan CKD, namun dosis pemeliharaan dapat mencapai $300 \mathrm{mg}$ perhari walaupun menderita CKD. Direkomendasikan untuk meningkatkan dosis pemeliharaan alopurinol tiap 2 sampai 5 minggu untuk mendapatkan dosis yang efektif bagi penderita artritis gout, untuk itu perlu dilakukan monitor kadar asam urat tiap 2 sampai 5 minggu selama titrasi alopurinol (Khanna et al, 2012).

Febuxostat merupakan obat golongan xantin oksidase inhibitor yang direkomendasikan sebagai terapi hiperurisemia pada penderita artritis gout yang memiliki kontraindikasi ataupun intoleransi terhadap alopurinol (NICE, 2008). Febuxostat memiliki struktur yang berbeda dengan alopurinol, bersifat lebih poten terhadap xantin oksidase dan tidak memiliki efek terhadap enzim lain pada metabolisme purin dan pirimidin. Dosis yang disarankan adalah $80 \mathrm{mg}$ perhari, dan dapat ditingkatkan $120 \mathrm{mg}$ perhari bila target kadar asam urat tidak tercapai setelah 2 sampai 4 minggu (Edwards, 2009).

Obat lain yang diberikan pada artritis gout adalah probenesid, obat golongan urikosurik ini diberikan sebagai alternatif lini pertama pengobatan apabila didapatkan kontraindikasi terhadap obat golongan xantin oksidase inhibitor. Dosis yang diberikan pada orang dewasa yakni $500 \mathrm{mg}$, diberikan 2 kali perhari dan dosis maksimal 2 gram perhari. Namun obat ini tidak dapat diberikan pada penderita yang mengalami penurunan fungsi ginjal dan riwayat batu saluran kemih (Khanna et al, 2012).

\section{Komplikasi}

Menurut Rotschild (2013), komplikasi dari artritis gout meliputi severe degenerative arthritis, infeksi sekunder, batu ginjal dan fraktur pada sendi. Sitokin, kemokin, protease, dan oksidan yang berperan dalam proses inflamasi akut juga berperan pada proses inflamasi kronis sehingga menyebabkan sinovitis kronis, dekstruksi kartilago, dan erosi tulang. Kristal monosodium urat dapat mengaktifkan kondrosit untuk mengeluarkan IL-1, merangsang sintesis nitric oxide dan matriks metaloproteinase yang nantinya menyebabkan dekstruksi kartilago. Kristal monosodium urat mengaktivasi osteoblas sehingga mengeluarkan sitokin dan menurunkan fungsi anabolik yang nantinya berkontribusi terhadap kerusakan juxta artikular tulang (Choi et al, 2005).

Artritis gout telah lama diasosiasikan dengan peningkatan resiko terjadinya batu ginjal. Penderita dengan artritis gout membentuk batu ginjal karena urin memilki $\mathrm{pH}$ rendah yang mendukung terjadinya asam urat yang tidak terlarut (Liebman et al, 2007). Terdapat tiga hal yang signifikan kelainan pada urin yang digambarkan pada penderita dengan uric acid nephrolithiasis yaitu hiperurikosuria (disebabkan karena peningkatan kandungan asam urat dalam urin), rendahnya $\mathrm{pH}$ (yang mana menurunkan kelarutan asam urat), dan rendahnya volume urin (menyebabkan peningkatan konsentrasi asam urat pada urin) (Sakhaee dan Maalouf, 2008).

\section{Prognosis}

Prognosis artritis gout dapat dianggap sebuah sistem bukan penyakit sendiri. Dengan kata lain prognosis penyakit artritis gout merupakan prognosis penyakit yang menyertainya (Tehupeiroy, 2003). Artritis gout sering dikaitkan dengan morbiditas yang cukup besar, dengan episode serangan akut yang sering menyebabkan penderita cacat. Namun, artritis gout yang diterapi lebih dini dan benar akan membawa prognosis yang baik jika kepatuhan penderita terhadap pengobatan juga baik (Rothschild, 2013).

Jarang artritis gout sendiri yang menyebabkan kematian atau fatalitas pada penderitanya. Sebaliknya, artritis gout sering terkait dengan beberapa penyakit yang berbahaya dengan angka mortalitas yang cukup tinggi seperti hipertensi, dislipidemia, penyakit ginjal, dan obesitas. Penyakit-penyakit ini bisa muncul sebagai komplikasi maupun komorbid dengan kejadian artritis gout (Tehupeiroy, 2003).

Dengan terapi yang dini, artritis gout dapat dikontrol dengan baik. Jika serangan artritis gout kembali, pengaturan kembali kadar asam urat (membutuhkan urate lowering therapy dalam jangka panjang) dapat mempengaruhi aktivitas kehidupan penderita. Selama 6 sampai 24 bulan pertama terapit artritis gout, serangan akut akan sering terjadi (Schumacher et al, 2007). Luka kronis pada kartilago intraartikular dapat mengakibatkan sendi lebih mudah terserang infeksi. Tofus yang mengering dapat menjadi infeksi karena penumpukan bakteri. Tofus artritis gout kronis yang tidak diobati dapat mengakibatkan kerusakan pada sendi. Deposit dari kristal monosodium urat di ginjal 
dapat mengakibatkan inflamasi dan fibrosis, dan menurunkan fungsi ginjal (Rothschild, 2013).

Pada tahun 2010, artritis gout diasosiasikan sebagai penyebab utama kematian akibat penyakit kardiovaskuler. Analisis 1383 kematian dari 61527 penduduk Taiwan menunjukkan bahwa individu dengan artritis gout dibandingkan dengan individu yang memiliki kadar asam urat normal, hazard ratio (HR) dari semua penyebab kematian adalah 1,46 dan HR dari kematian karena penyakit kardiovaskuler adalah 1,97. Sedangkan individu dengan artritis gout, HR dari semua penyebab kematian adalah 1,07, dan HR dari kematian karena penyakit kardiovaskuler adalah 1,08 (Kuo et al, 2010).

\section{KESIMPULAN}

Artritis gout merupakan gangguan metabolik yang pertama kali dijabarkan oleh Hippocrates pada masa Yunani kuno. Artritis gout dapat primer (akibat langsung overproduksi atau penurunan ekskresi asam urat) atau sekunder (terjadi bila overproduksi atau penurunan eskresi asam urat merupakan akibat proses penyakit lain,obat-obatan, atau konsumsi purin. Kristal monosodium urat monohidrat terbentuk dalam sendi dan jaringan sekitar serta berperan pada reaksi radang akut yang berkembang, menyebabkan nyeri berat. Faktor resiko dari penyakit artritis gout adalah: 1) usia diatas 40 tahun dan jenis kelamin yang lebih dominan pada pria, 2) medikasi seperti penggunaan obat diuretik, 3) obesitas, 4) konsumsi purin dan alkohol. Terdapat 4 stadium perkembangan klinis artritis gout, yaitu hiperurisemia asimtomatik, artritis gout akut, stadium interkritikal, dan stadium artritis gout kronis. Artritis gout menyerang terutama pada pria dewasa usia 40 tahun keatas dan pada wanita postmenopause. Pengobatan artritis gout tergantung pada stadium. Hiperurisemia asimtomatik biasanya tidak memerlukan pengobatan, sedang artritis gout akut dapat diobati dengan analgesik, NSAID, glukokortikoid sistemik dan artikular. Jika tidak tertangani dengan baik, maka dapat mengakibatkan komplikasi seperti severe degenerative arthritis, infeksi sekunder, batu ginjal dan fraktur pada sendi. Prognosis artritis gout baik jika terapi dilakukan lebih dini dan dilakukan dengan cara yang tepat.

\section{DAFTAR PUSTAKA}

Baker JF, Schumacher R 2010, Update on Gout and Hyperuricemia, International Journal Clinical Practice, Vol. 64, No. 3, pp.371-377

Busso N, So A 2010, Mechanisms of Inflammation in Gout, Arthritis Research and Therapy, diakses 5 Agustus 2013,

http://arthritis-research.com/content/12/2/206

Carter, MA 2006, Gout dalam Patofosiologi: Konsep Klinis Proses-proses Penyakit, EGC, Jakarta pp. 1402-1405

Chen et al. 2013, Impact of Obesity and Hypertriglyceridemia on Gout Development With or Without Hyperuricemia: A Prospective Study, Arthritis Care and Research, Vol. 65, No. 1, pp. 133-140

Choi et al. 2005, Pathogenesis of Gout, American College of Physicians, pp. 499-516
Cronstein BN, Terkeltaub R 2006, The Inflammatory Process of Gout and Its Treatment, Arthritis Research and Therapy, diakses 5 Agustus 2013, http://arthritisresearch.com/content/8/S1/S3

Dalbeth N, Haskard DO 2005, Mechanisms of Inflammation in Gout, Oxford Journals, pp. 1090-1096

Departemen Kesehatan Republik Indonesia 2006, Pharmaceutical Care Untuk Pasien Penyakit Artritis Rematik, Jakarta

Doherty, M 2009, New Insights Into The Epidemiology of Gout, Oxford Journals, pp. ii2-ii8

Edwards, NL 2009, Febuxostat: A New Treatment for Hyperuricemia in Gout, Oxford Journals, pp. ii15-119

Fauci et al. 2008, Gout, Pseudogout, and Related Disease in Harrisons's Manual of Medicine 17th Edition, The McGraw Hill Companies, USA pp. 903-904

Hensen, TRP 2007, Hubungan Konsumsi Purin Dengan Hiperurisemia Pada Suku Bali di Daerah Pariwisata Pedesaan, Jurnal Penyakit Dalam, Vol. 8, No. 1, pp. 38

Hidayat, R 2009, Gout dan Hiperurisemia, Medicinus, Vol. 22, No. 1, Divisi Reumatologi Departemen Ilmu Penyakit Dalam Fakultas Kedokteran Universitas Indonesia, Jakarta

Jordan et al. 2007, Rheumatology Guideline for the Management of Gout, The British Society for Rheumatology,

Khanna et al. 2012, Guidelines for Management of Gout. Part 1: Systematic Nonpharmacologic and Pharmacologic Therapeutic Approaches to Hyperuricemia, American College of Rheumatology, Vol. 64, No. 10, pp. 14311446

Khanna et al. 2012, Guidelines for Management of Gout. Part 2: Therapy and Antiinflammatory Prophylaxis of Acute Gouty Arthritis, American College of Rheumatology, Vol. 64, No. 10, pp. 1447-1461

Kuo et al, 2010, Gout: An Independent Risk Factor for Allcause and Cardiovascular Mortality, Rheumatology $\mathrm{Ox}$ ford, Vol. 49, No. 1, pp. 141-146

Liebman et al. 2007, Urid Acid Nephrolithiasis, Current Rheumatology Reports, Vol. 9, No. 3, pp. 251-257

Mandell, BF 2008, Clinical Manifestations of Hyperuricemia and Gout, Cleveland Clinic Journal of Medicine, Vol. 75, No. 5, pp. S5-S8

Muniroh et al 2010, Minyak Atsiri Kunyit Sebagai Anti Radang Pada Penderita Gout Artritis Dengan Diet Tinggi Purin, Makara-Kesehatan, Vol. 14, No. 2, pp. 58

Nainggolan, O 2009, Prevalensi dan Determinan Penyakit Rematik di Indonesia, Majalab Kedokteran Indonesia, Vol. 59, No 12, pp. 589

Neogi, T 2011, Clinical Practice of Gout, The New England Journal of Medicine, pp. 443-447

Nuki G, Simkin PA. 2006, A Concise History of Gout and Hyperuricemia and Their Treatment, Arthritis Research and Therapy, diakses 4 Agustus 2013, http://arthritisresearch.com/content/8/S1/S1

Purwaningsih, T 2009, "Faktor-faktor Risiko Hiperurisemia", Tesis, Universitas Diponegoro

Roddy, E dan Doherty, M 2010, Epidemiology of Gout, Arthritis Research and Therapy, diakses 4 Agustus 2013, http://arthritisresearch.com/content/12/6/223 
Rotschild, BM 2013, Gout and Pseudogout, Emedicine Medscape, diakses 2 August 2013,http:// www.emedicine. medscape. com/article/329958-author Saag KG, Choi H 2006, Epidemiology, Risk Factors and Lifestyle Modifications for Gout, Arthritis Research and Therapy, diakses 4 Agustus 2013, http://arthritisresearch.com/content/8/S1/S2

Sakhaee K, Maalouf NM 2008, Metabolic Syndrome and Uric Acid Nephrolithiasis, Seminars in Nephrology, Vol. 28, No. 2, pp. 174-180

Schumacher et al. 2007, Outcome Evaluations in Gout, Journal Rheumatol, Vol.34, No. 6, pp. 1381-1385

Schumacher HR, Chen LX 2008, Gout and Others CrystalAssociated Arthropathies in Harrison's Principle of Internal Medicine 17th Edition, The McGraw Hill, USA pp. 2165

Setter SM, Sonnet TS 2005, New Treatment Option in the Management of Gouty Arthritis, US Pharmacist,

Silbernagl, S 2006, Acid Base Homeostatis in Color Atlas of Physiology, Thieme, New York

Soriano et al. 2011, Contemporary Epidemiology of Gout in The UK General Population, NCBI, diakses 2 August 2013, http://www.ncbi.nlm.nih.gov/pmc/ articles/PMC3132018

Sunkureddi et al. 2006, Clinical Signs of Gout, Review of Clinical Signs, pp. 39-42

Talarima et al. 2012, Faktor Risiko Gouty Athritis di Kota Masohi Kabupaten Maluku Tengah Tahun 2010, Makara-Kesehatan, Vol. 16, No. 2 pp. 90

Tehupeiory, ES 2006, Artritis Gout dalam Buku Ajar Ilmu Penyakit Dalam, FKUI, Jakarta pp. 1208-1210

Terkeltaub, R 2009, Novel Therapies for Treatment of Gout and Hyperuricemia, Arthritis Research and Therapy, diakses 5 Januari 2013, http://arthritisresearch.com/content/11/4/236

Weaver, AL 2008, Epidemiology of Gout, Cleveland Clinic Journal of Medicine, Vol. 75, No. 5, pp. S9-S10

Wesselman et all. 2005, Gout Basics, Bulletin on the Rheumatic Diseases for Evidence Based Management of Rheumatic Diseases, Vol. 50, No. 9, pp. 1-3

Wilmana, PF dan Gan, S 2008, Analgesik-Antipiretik, Analgesik Anti-inflamasi Nonsteroid dan Obat Gangguan Sendi Lainnya dalam Farmakologi dan Terapi Edisi 5, Departemen Farmakologi dan Terapeutik FKUI, Jakarta pp. 230-244

Zhang et al. 2006, Alcohol Consumption as a Trigger of Recurrent Gout Attacks, The American Journal of Medicine, pp. 800.e13-800.e18

Zhu et al 2011, Prevalence of Gout and Hyperuricemia in the US General Population, American College of Rheumatology, pp. 3136 